\title{
Geoecological agricultural lands of the Altai region of the Republic of Khakassia
}

\author{
Ekaterina V. Pavlova ${ }^{1 *}$, Anastasiia I. Volkova ${ }^{1}$, and Ekaterina A. Demina ${ }^{1}$ \\ ${ }^{1}$ Institute of Natural Sciences and Mathematics, Katanova Khakass State University, 655000, Abakan, \\ 90 Lenin avenue., Russia Federation
}

\begin{abstract}
The article discusses the issue of application geographic information systems for inventory agricultural land and assessment of their condition. A geoinformation project has been developed for conducting geoecological appraisals agricultural land of the Altai region of the Republic of Khakassia. The structure of agricultural land, the area determined fallow lands and an inventory of forest belts investigated territory has been studied based on analysis of the agricultural map of scale 1: 100,000, interpretation of Landsat 4-5, 7, 8 and Sentinel 1 and 2 images, and also ground based satellite research. To processes overgrowth tree and shrub vegetation the deposits subject were revealed. The research results showed that on the study area in the structure of agricultural lands 56860 hectares of land belong to the deposits located on different stages of recovery. The elm overgrowing processes covered about 28580 hectares of post-agrogenic lands.
\end{abstract}

The State program of the Republic of Khakassia «The development of agro-industrial complex of the Republic of Khakassia and the social sphere in the countryside» provides increasing in production and processing of main types of products crop production, development of small business in the countryside, as well as increasing productivity and sustainability of agricultural production and fertility soil by means of complex land reclamation in the face of climate change and natural anomalies [1]. The implementation of the assigned tasks primarily depends on turn from the efficiency of the use of agricultural land. Unfortunately, the all-Russian tendency to increase the share of unused arable lands (fallow lands) and lands with lost fertility, which is typical for The Republic of Khakassia, does not contribute to the solution of the above tasks.

Solving the problems of rational use of land resources requires relevant information of the actual ratio of agricultural land (arable land, hayfields, pastures, deposit, etc.) in agricultural landscapes, their features use, degradation processes (salinization, overgrowth, erosion, etc.), condition of shelter and pasture shelter belts, etc.

In this regard, the goal of our work is to create a geoinformational (GIS) project «The Geoecological Assessment agricultural land of the Altai region of the Republic of Khakassia» containing a series of maps reflecting the structure and current state of agricultural lands of the Altai region of the Republic of Khakassia.

\footnotetext{
* Corresponding author: eve21@yandex.ru
} 
The Altai region of the Republic of Khakassia is located in its southern part within Koibalskaya steppe of the South Minusinsk depression. The relief is an elevated, gently sloping plain with separate low ridges of hills and small closed lake basins. The main part of the territory characterized by absolute relief marks from 260 to $580 \mathrm{~m}$ above sea level. The climate of the region is sharply continental. Duration of the period with temperature below $0{ }^{\circ} \mathrm{C}$ averages $85-110$ days [2].

The amount of precipitation in May-July (the period of active vegetation of plants) varies from 170 to $210 \mathrm{~mm}$, and in general, from 370 to $490 \mathrm{~mm}$ of precipitation falls per year. The duration of the frost-free period within the study area varies from 105 to 115 days. The dryness index based on a ratio the sum of the average daily temperatures above $10^{\circ} \mathrm{C}$ and the amount of precipitation for May - July is 1,9-1,7 (arid - insufficiently humidified) [3]. An essential feature of the climate is constant and quite strong winds. The dominant annual cycle is the south-westerly winds. Dust storms are often observed.

The main types of soils are chestnut, southern chernozems and ordinary, often chipped with bedrock outcrops. Characteristically widespread development of sandy and sifted sandy loam soils. In the lakeside depressions, depressions, in the floodplains of rivers, meadowboggy, meadow, meadow chernozem or meadow chestnut soils. The alkali-saline soil are formed in conditions of sharp contrast water regime and alternating salinization and desalination.

According to geobotanical zoning of A.V. Kuminova (1970) the territory of the Altai region is a part of the Priabakan (Central-Khakass) geobotanical district of the Minusinsk Depression province [4].

Natural herbaceous vegetation preserved after the development of virgin lands by separate fragments are represented by small sod and large sod real steppes with their digression and crushed versions. By slopes uplands petrophytic true steppes are common and in the lakeside depressions halophytic vegetation. Woody shrub vegetation (willows, poplars) is usually confined to river valleys, birch groves are found in the eastern part of the region near the Yenisey river. On sandy soils Artificial pine forests are located in small tracts.

The following data are the result of many years of field research (2004-2020): the peculiarities of the use of agricultural land, the location of deposits and forest belts, their structure and preservation, the description of the stand in individual areas of fallows overgrown with wood shrub vegetation (species composition, age, trunk diameter and tree stand closeness). After the inventory the forest belts were divided into the following categories of preservation:

1 - not requiring restoration (100-70\% of the total length forest belt);

2 - with preservation of more than $50 \%$ (69-50\% of the total length of the forest belt);

3 - requiring restoration (49-10\% of the total length of the forest belt);

4 - lost (9-0\% of the total length of the forest belt).

With the help of ArcMap 10.1 the GIS project was created to conduct a geoecological assessment of agricultural land. That project included vector layers of farmland and forest belts and mosaics space images. The analysis of the following objects were made to create the GIS project: topographic maps (M 1: 100000), land use maps by regions (M 1: 100000, M 1: 50,000), public cadastral map of the Russian Federation, multispectral satellite images of the growing season (end of July - September) from 2009 to 2019 satellite images of Landsat 5, 7, 8 from the archive of the US Geological Survey (USGS, https://earthexplorer.usgs.gov) and Sentinel 1, 2A and 2B (URL:https://scihub.copernicus.eu), web services providing access to space high-resolution photography (ArcGis Online, Bing maps, Yandex maps, kosmosninki.ru) archival materials of satellite imagery from the interactive Google Earth Pro applications (spatial resolution about 0,5 m). Based on 30 selected multispectral images of 2019 in the ArcMar 10.1 program, a catalog of space images was created, the georeferencing was corrected, the color rendition 
of the mosaic was corrected with alignment in tone (color balancing, histogram normalization). The boundaries of the spread of overgrowth and the area of the contours of fields affected by overgrowing with trees and shrubs were clarified with the help of the created mosaic of images from 2018-2019 from the end of July to September.

A vector line layer digitizing of the current location of forest belts was carried out according to field research data and actual satellite pictures. To assess the retrospective state of forest belts, we used agricultural maps of the Altai region.

The ArcMap working project settings are the following: coordinate system WGS 1984 UTM Zone 46N, Mercator / WGS84 projection. The project includes vector linear layers: rivers, roads of various categories, boundaries of districts, forest belts and areal vector layer of farmland. According to field research, web services and visual decoding of space images, data on the types of land and the degree of overgrowth of deposits were entered into attributive information of the areal vector layer of agricultural fields. In the linear layer of forest belts indicated the category of their safety, length, number of stripes and tree species. By the results of the analysis of the attribute information were calculated arable land, hayfields, pastures and post-agrogenic territories with different degree of overgrowth.

To assess the process of overgrowth with vegetation, the following stages of overgrowth were identified:

1. Zero stage of overgrowth - there are no overgrowing processes.

2. The first stage of overgrowth - undergrowth of tree species appears commensurate with the herbaceous layer with a projective cover of up to $50-100 \%$, especially near the parent plantations (forest belts).

3. The second stage of overgrowth - thinning of the undergrowth begins due to biological characteristics of the elm (a large percentage of frosting of plants), the density of the stand is reduced to $0,3-0,5$.

4. The third stage of overgrowth is further thinning of the stand. Completeness is very low $\leq 0,1$. The average height of the elm is at least $2 \mathrm{~m}$ (as a rule the age of the plantings is over 8 years). Young undergrowth reappears [5].

The area of the Altai Municipal District is 173,61 thousand ha of which agricultural land (163,85 thousand ha) occupy $94,4 \%$ of the total area of the district. The soils on the territory of the region are mainly of low and medium unstable fertility and are mainly suitable for fodder land and use as arable land with limited sowing of row crops. In this regard, most of the agricultural land is not involved in the cultivation of agricultural crops and is represented by deposits at various stages of recovery (mainly wormwood-cereal and fire-wheatgrass deposits) (fig. 1).

Arable land is cultivated, and crops are grown mainly in the eastern and south-eastern parts of the Altai region within the Kirovsky, the Novomikhaylovsky and the Novorossiysk village councils. It is here that soils with high sustainable fertility are located, which are suitable for growing all agricultural crops. In total, as arable land in 2018-2019 about 55 thousand hectares were used. On the territory of the Altai district, 56860 hectares of agricultural land (32,5\% of the total area of the district) are deposits at different stages of restoration. They are used for mowing in some wetter years. The process of demutation that has taken place on fallow lands in recent decades is significantly changing and slowing down due to the spread of the squat elm (Ulmus pumila L.). This tree species quite resistant to various influences (arid conditions, pests, pruning, etc.), acts as the basis of most of the forest shelter belts in Khakassia, including those within the Altai region. Elm forest belts act as a mother stand and centers of occurrence and development of overgrowing processes. 


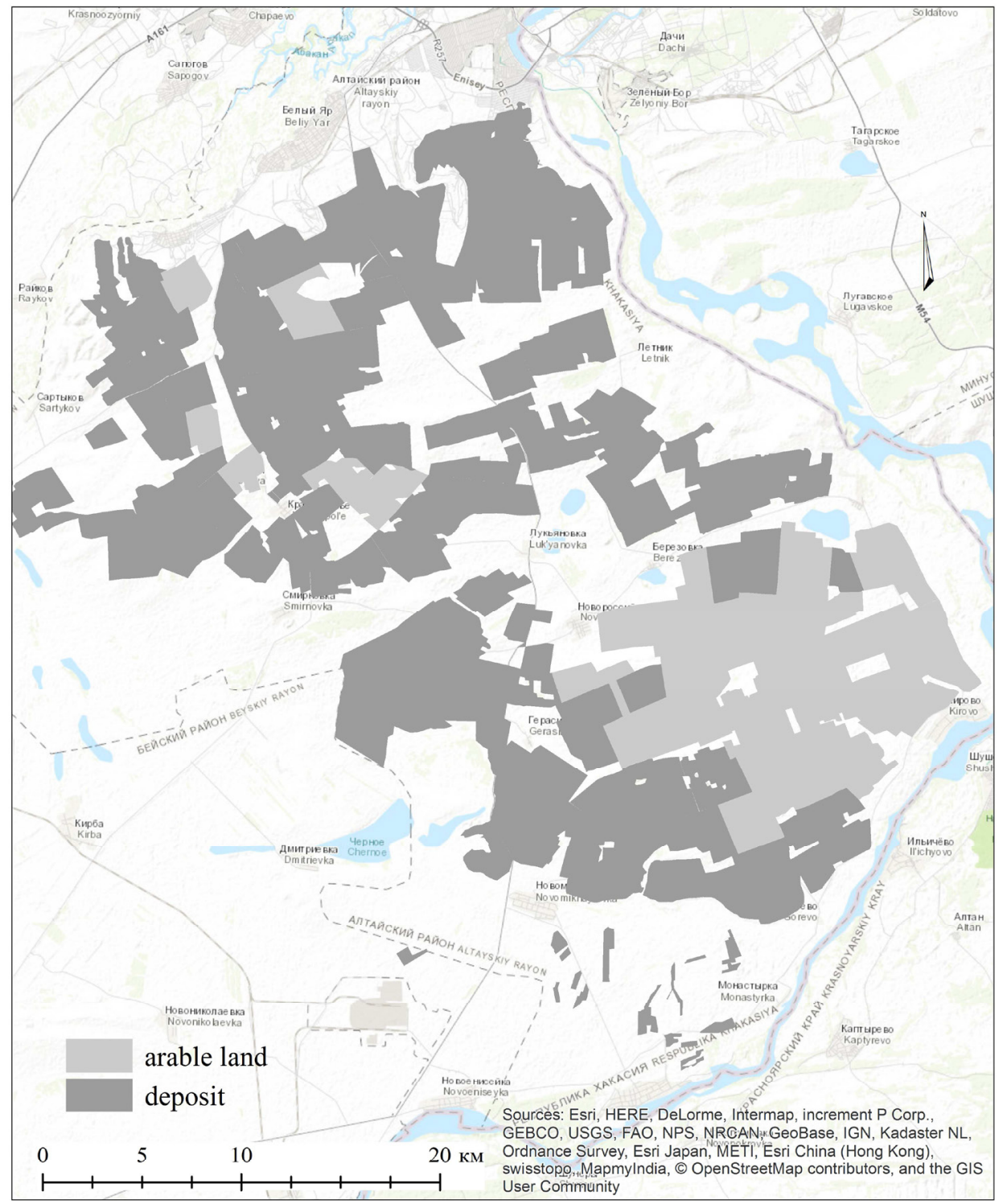

Fig. 1. Location of arable land and deposits in the Altai region.

It was revealed that in 2019 about 28580 hectares of post-agrogenic lands were covered by elm overgrowing processes. 7938 hectares of them are at the first stage of overgrowth, when undergrowth of tree species appears commensurate with the herbaceous layer with a projective cover of up to 50-100\%, especially near the parent plantations (forest belts). Share of deposits, in the second stage of overgrowth is $49,6 \%$ of the total area fallow lands (fig. 2). 


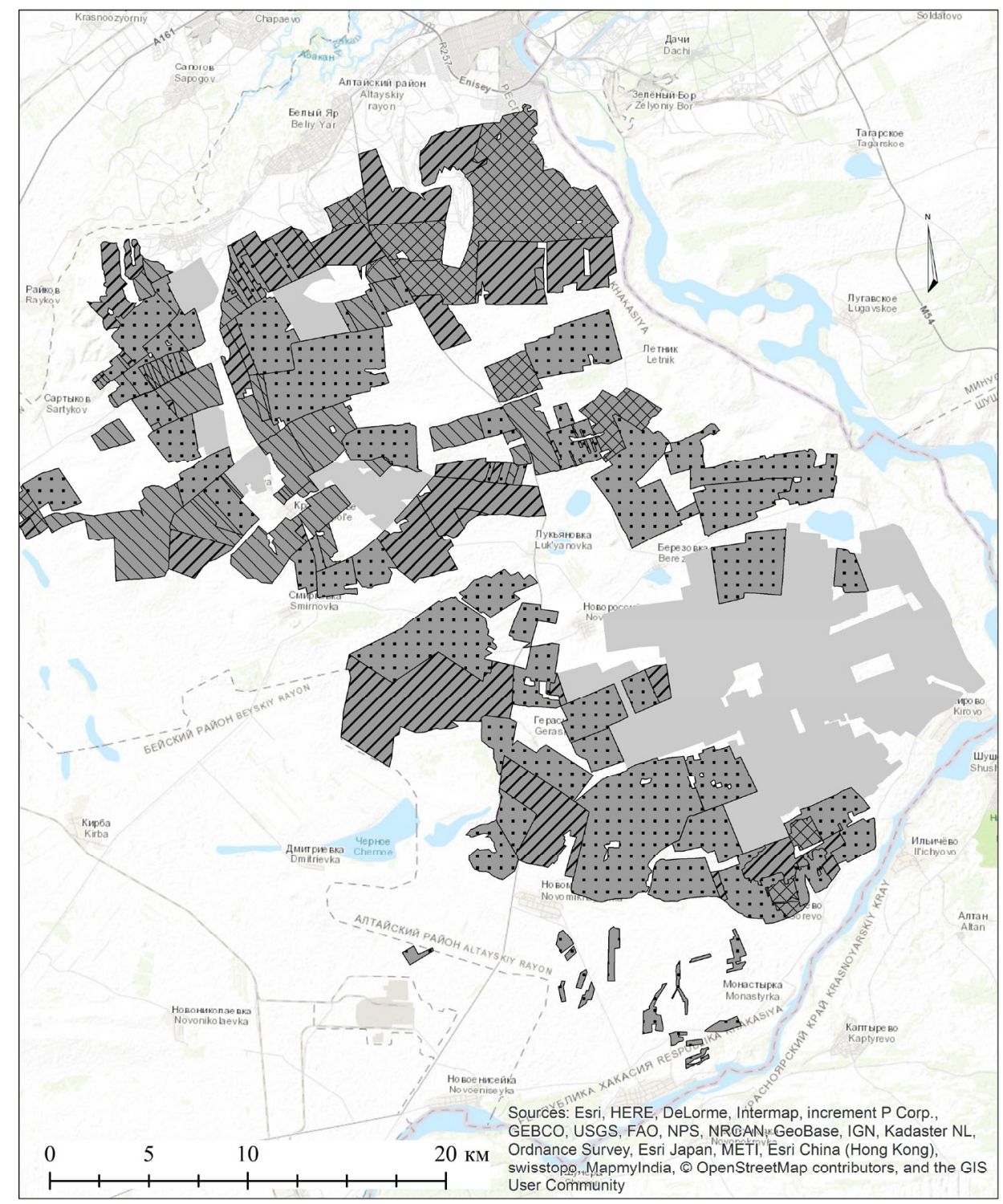

The degree of overgrowth
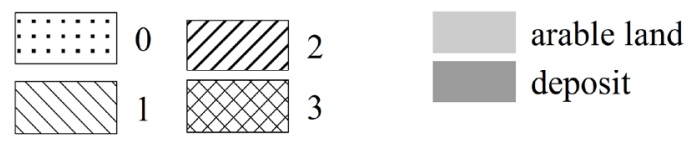

Fig. 2. Overgrowth of agricultural land by tree and shrub vegetation in the Altai region of Khakassia.

The title is set in bold 16-point Arial, justified. The first letter of the title should be capitalised with the rest in lower case. You should leave $22 \mathrm{~mm}$ of space above the title and $6 \mathrm{~mm}$ after the title.

The developed GIS project will provide land users with an up-to-date information on the structure of agricultural land and their condition can be used as a basis for drawing up a 
program for the use of lands with greater economic efficiency and with less environmental risk. The obtained results provide the basis for the development of an optimal placement of land and crops, the basis for the assessment of favorable and unfavorable consequences of environmental protection measures taken on the ecosystem as a whole and its individual components, making operational decisions on their adjustment depending on changing external conditions.

\section{References}

1. The decree of the Government of the Republic of Khakassia of November 19, 2012 no. 781 «On approval state program of the Republic of Khakassia «The Development of agroindustrial complex of the Republic of Khakassia and the social sphere in the countryside» (as amended by 31 July 2020). URL: http://docs.cntd.ru/document/453366265.

2. A. I. Volkova, E. V. Pavlova, E. A. Demina. RPERS 2020. pp. 177- 179 (2020).

3. South of the Krasnoyarsk Territory. Series of maps for agricultural planning, 40 p. (1977).

4. A. V. Kuminova, Y. M. Maskaev, G. A. Zvereva, Vegetation cover of Khakassia (Nauka Pbs., Novosibirsk, 1976) in Russian , 421 p. (1976).

5. E. V. Pavlova, A. I. Volkova, E. A. Demina. E3S Web of Conferences, 149, 03006 (2020). 